\title{
Purification and Properties of an Aminopeptidase from Buckwheat Seed
}

\author{
Kiyokazu IKeDA, Hiroshi OHMINAMI* and Takanori Kusano \\ Faculty of Nutrition, Kobe-Gakuin University, \\ Arise, Ikawadani-cho, Nishi-ku, Kobe 673, Japan
}

Received December 27, 1982

\begin{abstract}
An aminopeptidase was purified from buckwheat seed by using affinity chromatography, ionexchange chromatography and chromatofocusing. The enzyme had a molecular weight of 37,000 as determined by gel filtration. The aminopeptidase activity, determined with L-leucine- $p$-nitroanilide (Leu-pNA) as the substrate, exhibited a $\mathrm{pH}$ optimum of 7.2. The $K m$ value for Leu-pNA was $140 \mu \mathrm{M}$. The preferred substrates were L-leucine- $\beta$-naphtylamide and Leu-pNA, although there was also high activity against L-leucyl-L-alanine and L-leucinamide. Thiol antagonists were found to be potent inhibitors against the enzyme. The enzyme exhibited less or no sensitivity to the endogeneous proteinase inhibitors, benzamidine and TPCK.
\end{abstract}

Buckwheat (Fagopyrum esculentum Mönch) seed constitutes an important source of dietary proteins in some parts of the world. Noodle made from buckwheat flour-water dough is a long-established, most acceptable product in Japan. The major storage proteins of buckwheat seed contribute greatly to the noodlemaking quality of buckwheat flours. Any alterations of these proteins such as from proteolytic enzymes can have a beneficial or deleterious effect on the quality of resultant noodles from such flours. The storage proteins are synthesized during development of the buckwheat kernel together with other functional proteins including proteolytic enzymes. More information is needed on the properties of the proteolytic enzymes and their possible action on the storage proteins in buckwheat seed.

The present authors have presented evidence for the occurrence of trypsin inhibitors in buckwheat seed. ${ }^{1,2)}$ Although a proteolytic enzyme, measured as the capacity to hydrolyze benzoyl-D, L-arginine- $p$-nitroanilide, has been shown to occur in buckwheat seed, ${ }^{3,4)}$ no attempt has been made to determine whether the trypsin inhibitors present in buckwheat seed could inhibit endogeneous enzymes of the seed. In the course of studies devoted to elucidate this problem, the authors came to recognize that buckwheat seed should contain a proteolytic enzyme, which was presumably classified as a member of aminopeptidase. Sugiyama and Fukuba ${ }^{5)}$ have suggested its occurrence in the aqueous extract of commercial buckwheat flour. It is uncertain, however, whether this enzyme is associated with the noodle-making properties of flours made from buckwheat seed. Isolation and characterization of this enzyme will ultimately allow an evaluation of the influence of this enzyme towards the quality of resultant product from buckwheat seed.

The present paper describes the purification

* Present address: Nomura Tsukudani Co., Tahara, Ohkubo-cho, Uji 611, Japan.

Abbreviations: Leu-pNA, L-leucine- $p$-nitroanilide; Leu- $\beta \mathrm{NA}$, L-leucine- $\beta$-naphtylamide; Leu- $\mathrm{NH}_{2}$, L-leucinamide; Leu-Gly, L-leucyl-glycine; Leu-Ala, L-leucyl-L-alanine; Gly-Leu, glycyl-L-leucine; Leu-Gly-Gly, L-leucyl-glycyl-glycine; Ac-Ala-pNA， $N$-acetyl-L-alanine- $p$-nitroanilide; Suc-[Ala $]_{3}$-pNA, succinyl-L-alanyl-L-alanyl-L-alanine- $p$-nitroanilide; Bzl-Cys-pNA, $S$-benzyl-L-cysteine- $p$-nitroanilide; $\gamma$-Glu-pNA, L- $\gamma$-glutamyl- $p$-nitroanilide; BApNA, $\alpha-N$-benzoyl-D,Larginine- $p$-nitroanilide; BTpNA, benzoyl-L-tyrosine- $p$-nitroanilide; SBTI, soybean trypsin inhibitor; $\mathrm{pCMB}, p$ chloromercuribenzoic acid; TLCK, $p$-toluenesulfonyl-L-lysine chloromethyl ketone; TPCK, $p$-toluenesulfonyl-Lphenylalanine chloromethyl ketone. 
and characterization of an aminopeptidase from buckwheat seed.

\section{MATERIALS AND METHODS}

Materials. Fresh and mature buckwheat seeds were purchased locally and stored at $4^{\circ} \mathrm{C}$ until use. Leu-pNA and BApNA were obtained from Nakarai Chemicals Co. and Boehringer Mannheim Co., respectively. All other substrates for enzyme assay were purchased from Nakarai Chemicals Co. Trypsin (from bovine pancreas), pepsin (from hog stomach mucosa), SBTI and ovalbumin were obtained from Sigma Chemicals Co. The buckwheat trypsin inhibitors used in this study were isolated in a partiallypurified form on trypsin-bound Sepharose $4 B$ as described previously. ${ }^{2)} \mathrm{AH}-\mathrm{Sepharose} 4 \mathrm{~B}$, DEAE-Sepharose CL-6B, polybuffer exchanger PBE 94, polybuffer PB 74, Sephacryl S-200 and Sephadex G-25 were products of Pharmacia Fine Chemicals. All other chemicals used were of analytical grade.

L-Leucine was used as a ligand for affinity chromatography. The ligand was coupled to $\mathrm{AH}$-Sepharose $4 \mathrm{~B}$, with 1,6-diaminohexane as a spacer, using $N$-ethyl- $N^{\prime}$-(3dimethyl aminopropyl) carbodiimide hydrochloride. The column $(6.0 \times 4.0 \mathrm{~cm})$ was equilibrated with $0.05 \mathrm{M}$ Tris$\mathrm{HCl}$ buffer (pH 7.5).

Purification of the aminopeptidase. The purification procedure was conducted at $0 \sim 4^{\circ} \mathrm{C}$. Finely-ground buckwheat seed meal was extracted with $0.05 \mathrm{M}$ Tris- $\mathrm{HCl}$ buffer ( $\mathrm{pH} 7.5)$ for $1 \mathrm{hr}$ and a 5:1 buffer-to-meal ratio with stirring. After extraction, the suspension was clarified by centrifugation $(10,000 \times g, 15 \mathrm{~min})$. An equal volume of the above buffer solution was then added to the supernatant. The solution obtained was applied on an affinity column of leucine-bound Sepharose 4B. Enzymes bound to the affinity resin were eluted with the same buffer containing $0.3 \mathrm{M} \mathrm{NaCl}$. The active fraction obtained was further fractionated by ion-exchange chromatography on DEAE-Sepharose CL-6B in $0.05 \mathrm{M}$ Tris- $\mathrm{HCl}$ buffer (pH 7.5) containing $1 \mathrm{~mm} 2$-mercaptoethanol using a linear gradient of $0 \sim 0.35 \mathrm{M} \mathrm{NaCl}$. The enzyme fraction obtained was then subjected to chromatofocusing, the enzyme solution being applied to a column $(40 \times 1.0 \mathrm{~cm})$ of polybuffer exchanger PBE 94, which had been pre-equilibrated against $25 \mathrm{~mm}$ Tris- $\mathrm{HCl}$ buffer $(\mathrm{pH}$ 7.2). The active fraction by this procedure was pooled, desalted by chromatography on a column of Sephadex G-25, and lyophilized. Gel electrophoresis with $7.5 \%$ gel (pH 8.6) confirmed the homogeneity of the sample so obtained.

Enzymatic assays. Aminopeptidase activity was routinely assayed using Leu-pNA as the substrate according to the procedure of Apple. ${ }^{6)}$ Enzymes sufficient to give a convenient rate of hydrolysis were added to the reaction mixture which consisted of the following in the final concentration: Leu-pNA, $2 \mathrm{~mm}$; and Tris- $\mathrm{HCl}$ buffer $(\mathrm{pH}$ 7.2), $0.1 \mathrm{~mm}$. The reaction was carried out at $35^{\circ} \mathrm{C}$ for $20 \mathrm{~min}$ and stopped by the addition of $1.0 \mathrm{ml}$ of $20 \%$ acetic acid. One unit of enzyme activity is defined as the conversion of $1 \mu \mathrm{mol}$ of substrate per minute. Specific activity is defined in terms of $1 \mathrm{unit} / \mathrm{mg}$ of protein. The hydrolytic activities of the enzyme against Ac-Ala-pNA, Bzl-CyspNA, $\gamma$-Glu-pNA, Suc-[Ala $]_{3}$-pNA, BApNA and BTpNA were determined by measuring the amounts of $p$ nitroaniline liberated from the substrates from their spectrophotometer readings at $410 \mathrm{~nm}$; the activities against Leu- $\beta$ NA, Leu-NH ${ }_{2}$, Leu-Gly, Leu-Ala, Gly-Leu and Leu-Gly-Gly were determined by measuring the amounts of L-leucine liberated from the substrates with a Yanaco LC-8 amino acid analyzer.

Other analyses. The molecular weight of the enzyme was estimated by the molecular sieving method using Sephacryl S-200 $(72 \times 3.6 \mathrm{~cm})$ in $0.05 \mathrm{M}$ Tris- $\mathrm{HCl}$ buffer (pH 7.5) containing $0.2 \mathrm{M} \mathrm{NaCl}$ and $1 \mathrm{~mm} \quad 2$ mercaptoethanol.

The distribution of protein in the column effluents was determined by $A_{280}$ measurements. Protein concentration was obtained using the method of Lowry et al. ${ }^{7)}$ Disc gel electrophoresis was carried out in $7.5 \%$ polyacrylamide gel at $\mathrm{pH} 8.6$ by the procedure of Davis. ${ }^{8)}$

\section{RESULTS AND DISCUSSION}

\section{Purification of the aminopeptidase}

The buckwheat aminopeptidase was separated quantitatively from the bulk of the seed proteins by affinity chromatography on leucine-bound Sepharose 4B (Fig. 1). The protein peak which eluted with the starting buffer, $0.05 \mathrm{M}$ Tris- $\mathrm{HCl}$ buffer ( $\mathrm{pH} 7.5$ ), showed no enzymatic activity. Enzymes bound to the affinity resin were eluted by $0.3 \mathrm{M} \mathrm{NaCl}$ in the same buffer. The active fraction obtained was fractionated by ion-exchange chromatography on DEAE-Sepharose CL-6B (Fig. 2). This chromatography resulted in the appearance of a single peak of enzyme activity. The enzymatically-active fraction was applied to a column of polybuffer exchanger PBE 94, which had been pre-equilibrated against $25 \mathrm{~mm}$ Tris$\mathrm{HCl}$ buffer ( $\mathrm{pH}$ 7.2). Polybuffer 74 at $\mathrm{pH} 4.0$ (diluted 1:10 from the stock solution), $5 \mathrm{ml}$, was applied to the column, followed by $3 \sim 8 \mathrm{ml}$ aminopeptidase solutions. Finally, polybuffer 74, $\mathrm{pH} 4.0$, was added at a flow rate of $20 \mathrm{ml} / \mathrm{hr}$. Aminopeptidase was separated with 


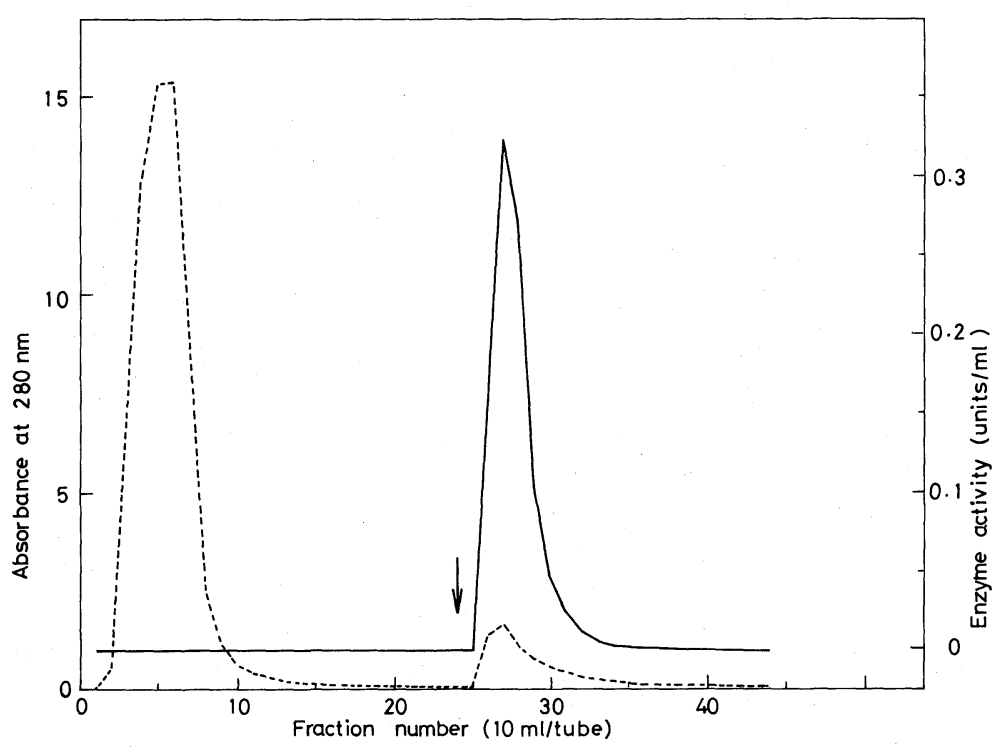

FIG. 1. Affinity Column Separation of Buckwheat Aminopeptidase.

Fifty milliliters of the diluted aqueous extract were added to a column $(6.0 \times 4.0 \mathrm{~cm})$ of leucine-bound Sepharose 4B. The arrow indicates a change of effluent from the extractant buffer to $0.3 \mathrm{M} \mathrm{NaCl}$ in the same buffer.

,$----- A_{280} ;--$, enzyme activity.

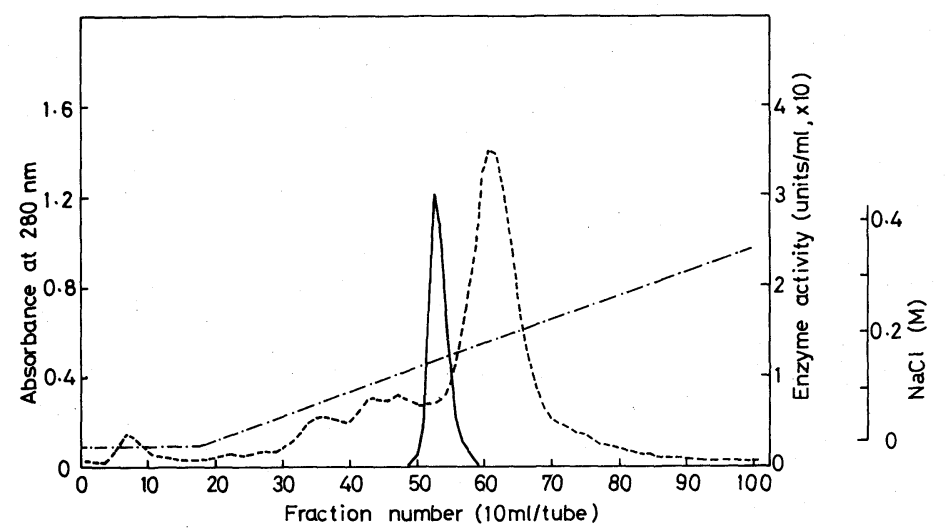

FIG. 2. Ion-exchange Chromatography of the Pooled Material Desorbed from Leucine-bound Sepharose $4 \mathrm{~B}$.

The ion exchanger (DEAE-Sepharose CL-6B) was equilibrated with an initial effluent buffer $(0.05 \mathrm{M}$ Tris- $\mathrm{HCl}$ buffer, $\mathrm{pH} 7.5$ ). The linear gradient limit was $0 \sim 0.35 \mathrm{~m}$ sodium chloride in the equilibrating buffer and the total volume of the gradient was $800 \mathrm{ml}$.

$----A_{280} ;-$, enzyme activity; --.--, $\mathrm{NaCl}$.

other inert proteins at $\mathrm{pH} 4.9$ (Fig. 3). On polyacrylamide gel electrophoresis, a single band was detected for the purified enzyme, even if about $50 \mu \mathrm{g}$ of protein was applied.

The buckwheat aminopeptidase was purified to a homogeneous state with a recovery of approximately $20 \%$ (Table I). The specific activity of the purified enzyme was 6.17 units/ mg protein, representing approximately 110 fold purification over the aqueous extract. 


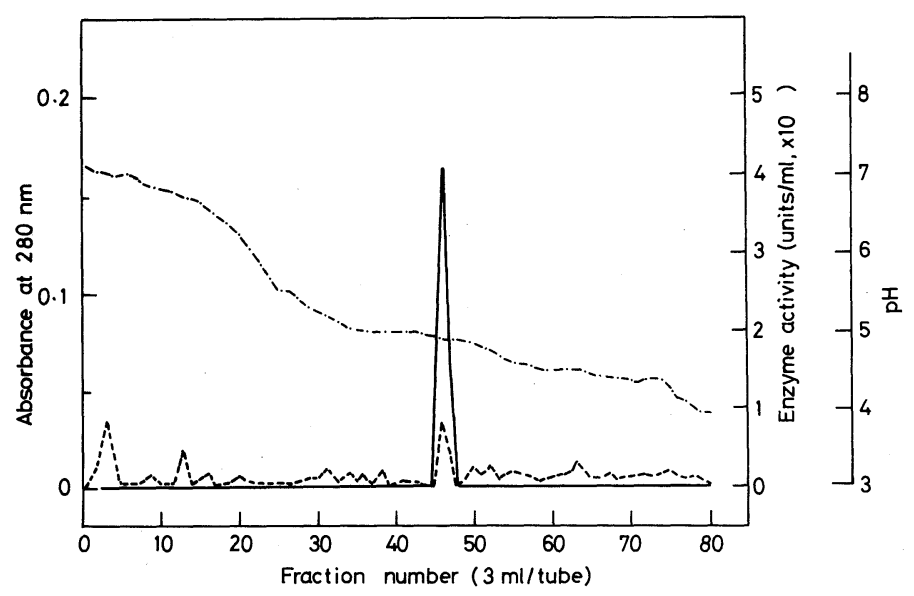

FIG. 3. Chromatofocusing of the Active Fraction Obtained from DEAE-Sepharose CL-6B Column Chromatography.

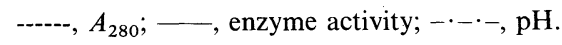

Table I. Purification of an Aminopeptidase from Buckwheat Seed

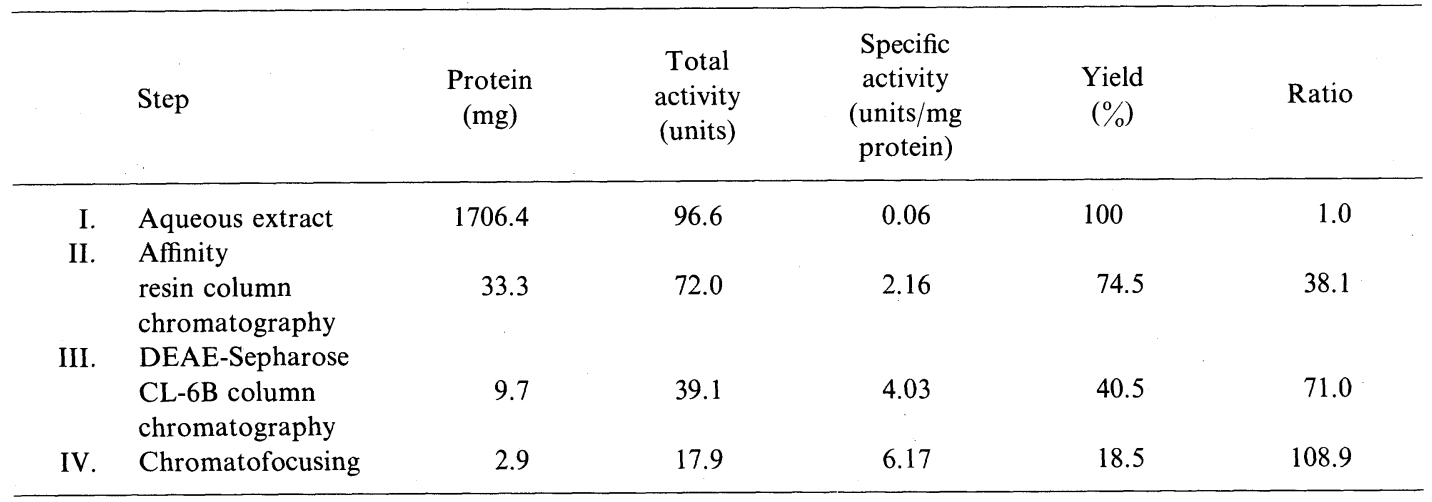

\section{Molecular weight estimation}

The molecular weight of the buckwheat aminopeptidase, as estimated by molecularsieve chromatography on Sephacryl S-200, was 37,000 (Fig. 4). Its molecular weight was a little lower in comparison with aminopeptidases found in other plant seeds..$^{9 \sim 12)}$

\section{pH Optimum and stability}

Aminopeptidase activity, determined with Leu-pNA as the substrate, exhibited a $\mathrm{pH}$ optimum of 7.2 (Fig. 5A). The kinetic parameters for Leu-pNA as the substrate were determined to be: $K m=1.4 \times 10^{-4} \mathrm{M}$, and $V_{\max }=4.5 \times 10^{-3} \mathrm{M} / \mathrm{min} / \mathrm{mg}$ protein.

The effect of $\mathrm{pH}$ on the stability of the enzyme was also studied. The enzyme was stable to changes of $\mathrm{pH}$ in the range of $4 \sim 8$ (Fig. 5B). Below $\mathrm{pH} 4$ and above $\mathrm{pH} 8$ the enzyme significantly lost its activity. The thermal stability of the aminopeptidase at $\mathrm{pH} 7.2$ has also been studied. The enzyme had a comparatively high degree of stability at $40^{\circ} \mathrm{C}$; there was about $10 \%$ loss of its original activity after heating for $10 \mathrm{~min}$ at $40^{\circ} \mathrm{C}$. The activity was much less stable at $50^{\circ} \mathrm{C}$ (data not shown).

\section{Substrate specificity}

The relative activities of the aminopeptidase against several substrates are presented in Table II. Of the substrates tested, Leu- $\beta$ NA demonstrated the highest degree of suscepti- 


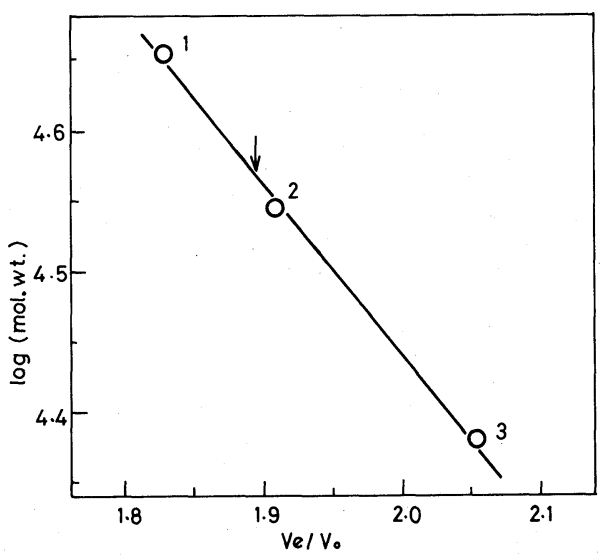

FIG. 4. Determination of the Molecular Weight of the Buckwheat Aminopeptidase by Molecular-sieve Chromatography with Sephacryl S-200.

The arrow indicates the enzyme. Standard proteins and their molecular weights are: 1 , ovalbumin $(45,000) ; 2$, pepsin $(35,000) ; 3$, trypsin $(24,000)$.
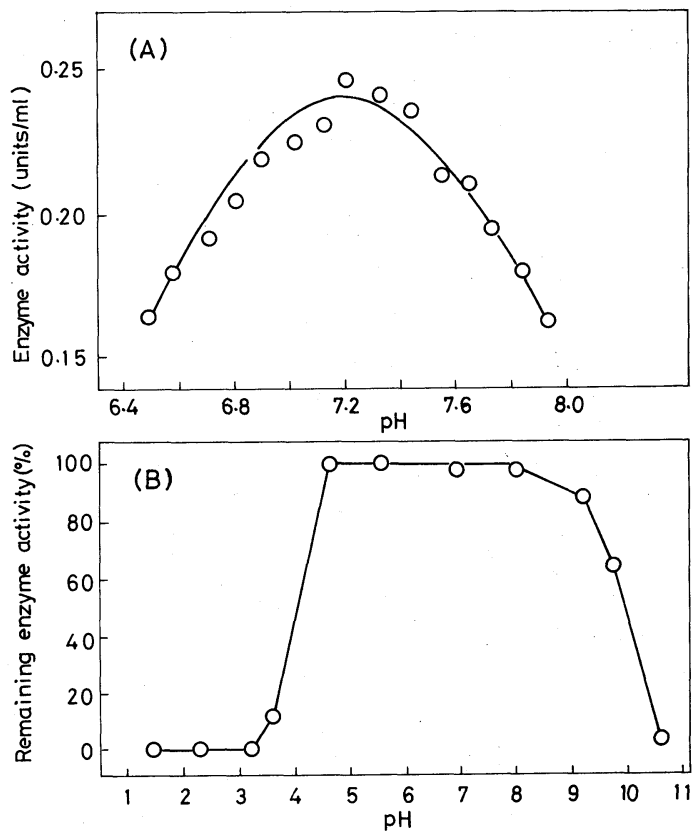

FIG. 5. The pH-dependence of the Activity (A) and the Stability (B) of Buckwheat Aminopeptidase.

(A), the enzyme activity was assayed in $0.05 \mathrm{M}$ phosphate buffer at various $\mathrm{pH}$ levels, $35^{\circ} \mathrm{C}$, for $20 \mathrm{~min}$ using LeupNA as the substrate.

(B), the enzyme solution $(20 \mu \mathrm{g} / \mathrm{ml})$ was adjusted at the indicated $\mathrm{pH}$ with $\mathrm{NaOH}, \mathrm{NaCl}$ or $\mathrm{HCl}$ (final ionic strength, 0.5).

The enzyme solution so obtained was incubated for $30 \mathrm{~min}$ at $37^{\circ} \mathrm{C}$, and then the remaining enzymatic activity against Leu-pNA as the substrate was assayed.
Table II. Substrate Specificity of BUCKWHEAT AMINOPEPTIDASE

Enzyme activity was determined using the indicated compound as substrate $(2 \mathrm{~mm})$. Assays were carried out in $100 \mathrm{~mm}$ Tris- $\mathrm{HCl}$ buffer ( $\mathrm{pH} 7.2$ ).

Activities are expressed relative to Leu-pNA.

\begin{tabular}{lc} 
Substrate & $\begin{array}{c}\text { Relative activity } \\
(\%)\end{array}$ \\
\hline Leu-pNA & 100 \\
Leu- $\beta$ NA & 208.7 \\
Leu-NH & 19.8 \\
Ac-Ala-pNA & nd \\
Suc-[Ala] $]_{3}$-pNA & nd \\
Bzl-Cys-pNA & nd \\
$\gamma$-Glu-pNA & nd \\
BApNA & nd \\
BTpNA & nd \\
Leu-Gly & 11.8 \\
Leu-Ala & 55.9 \\
Gly-Leu & 17.1 \\
Leu-Gly-Gly & 8.6 \\
\hline
\end{tabular}

nd, not detectable.

bility to hydrolysis. In addition, the preferred substrates for the enzyme were Leu-pNA, LeuAla, Leu- $\mathrm{NH}_{2}$, Gly-Leu and Leu-Gly. The enzyme was also found to liberate L-leucine from Leu-Gly-Gly, but the enzyme did not hydrolyze glycyl-glycine occurring from LeuGly-Gly. No activity towards Ac-Ala-pNA, Suc-[Ala $]_{3}$-pNA, Bzl-Cys-pNA and $\gamma$-GlupNA was observed. BApNA and BTpNA, endopeptidase substrates, were also not hydrolyzed by the enzyme. These results suggest that this enzyme is a true aminopeptidase requiring a free L-amino group on the substrate. The buckwheat aminopeptidase showed a substrate specificity relatively similar to aminopeptidases found in pea (AP-1) ${ }^{13)}$ and Agave americana. ${ }^{14)}$ Although the buckwheat enzyme exhibited high hydrolytic activity against the peptides with $\mathrm{NH}_{2}$-terminal leucine, its pattern of substrate specificity differs from that of a leucine aminopeptidase found in barley, ${ }^{15)}$ especially in terms of activities of each of the two enzymes against Leu$\beta \mathrm{NA}$ as the substrate. 
TABle III. EFFECTS OF INHIBITORS AND ACtIVATORS on BuCKWHEat Aminopeptidase

Inhibitors or activators were pre-incubated with the enzyme for $10 \mathrm{~min}$ at $35^{\circ} \mathrm{C}$ before assaying. The substrate for the enzyme was Leu-pNA. All the indicated substances, except for buckwheat trypsin inhibitor (1 mg) and SBTI (1 mg), were added to $1 \mathrm{~mm}$ (concentration in the final reaction mixture). Conditions for these assays are in the text.

\begin{tabular}{lc}
\hline Substance added & $\begin{array}{c}\text { Enzyme activity } \\
\text { remaining }(\%)\end{array}$ \\
\hline None & 100 \\
EDTA & 89 \\
Citrate & 99 \\
Imidazole & 103 \\
Cysteine & 86 \\
Iodoacetic acid & 57 \\
Iodoacetamide & 101 \\
pCMB & 30 \\
2-Mercaptoethanol & 105 \\
Dithiothreitol & 102 \\
HgCl & 05 \\
TPCK & 07 \\
TLCK & 82 \\
Benzamidine & 101 \\
Buckwheat trypsin & 96 \\
inhibitor & 103 \\
SBTI & \\
\hline
\end{tabular}

TABLE IV. EFFECTS OF VARIOUS IONS ON BUCKWHEAT AMINOPEPTIDASE

Ions were pre-incubated with the enzyme for $10 \mathrm{~min}$ at $35^{\circ} \mathrm{C}$ before assaying. The substrate for the enzyme was Leu-pNA. All the ions examined were added to $5 \mathrm{~mm}$ (concentration in the final reaction mixture).

\begin{tabular}{cc}
\hline Ion added & $\begin{array}{c}\text { Enzyme activity } \\
\text { remaining }(\%)\end{array}$ \\
\hline None & 100 \\
$\mathrm{~K}^{+}$ & 97 \\
$\mathrm{Na}^{+}$ & 95 \\
$\mathrm{Ca}^{2+}$ & 89 \\
$\mathrm{Mg}^{2+}$ & 93 \\
$\mathrm{Mn}^{2+}$ & 99 \\
$\mathrm{Hg}^{2+}$ & 0 \\
$\mathrm{Cu}^{2+}$ & 0.2 \\
\hline
\end{tabular}

\section{Enzyme inhibitors and activators}

The results of the effects of the inhibitors and activators employed to classify peptide hydrolases are summarized in Table III. The sulhydryl reagents, $\mathrm{pCMB}$ and $\mathrm{HgCl}_{2}$, were shown to be potent inhibitors of the enzyme. Iodoacetic acid also inhibited the activity of the enzyme. On the other hand, the enzyme was not affected by several chelating reagents, i.e., EDTA and citrate. The buckwheat trypsin inhibitors, SBTI, benzamidine and TPCK had little or no inhibitory capacity against the activity of the enzyme.

Various ions were also evaluated for their influence towards the enzyme (Table IV). Cupric ion, as well as $\mathrm{Hg}^{2+}$, almost completely diminished the enzyme activity. The enzyme was not affected by any of the other ions, including $\mathrm{Mg}^{2+}$ and $\mathrm{Mn}^{2+}$. These results suggest that the buckwheat aminopeptidase is a non-metallo, SH-peptidase (Tables III and IV).

Although the buckwheat aminopeptidase shows high affinity against L-leucine, this enzyme differs from the so-called leucine aminopeptidases, found in various mammalian sources, ${ }^{16)}$ with respect to these properties. The typical leucine aminopeptidases are activated by $\mathrm{Mg}^{2+}$ or $\mathrm{Mn}^{2+}$, and inactivated by chelating agents; and their molecular weight is usually high. On the other hand, in terms of antagonism by thiol inhibitors, non-sensitivity towards chelating agents and $\mathrm{pH}$-activity profile, the buckwheat aminopeptidase resembles the aminopeptidases found in barley ${ }^{9)}$ and pea (AP-1). ${ }^{13)}$ These similarities probably reflect some analogies in the respective reaction mechanisms.

Acknowledgment. This work was supported in part by a Grant-in-Aid for the Encouragement of Young Scientist (No. 57780064) to K. I. from the Ministry of Education, Science and Culture of Japan.

\section{REFERENCES}

1) K. Ikeda and T. Kusano, Agric. Biol. Chem., 42, 309 (1978).

2) K. Ikeda and T. Kusano, Agric. Biol. Chem., 47, 1481 (1983).

3) M. A. Belozerskii, I. B. Emtseba and T. A. Kursanoba, Dokl. Akad. Nauk SSSR, 209, 1215 (1973).

4) Y. E. Dunaevskii and M. A. Belozerskii, Biokhimiya, 45, 325 (1980).

5) N. Sugiyama and H. Fukuba, Kaseigaku Zasshi, 31, 
707 (1980).

6) W. Apple, "Methods of Enzymatic Analysis (2nd ed.)," Vol. 2, ed. H. U. Bergmeyer, Academic Press Inc., New York, N. Y., 1974, p. 949.

7) O. H. Lowry, N. J. Rosebrough, A. L. Farr and R. J. Randall, J. Biol. Chem., 193, 265 (1951).

8) B. J. Davis, Ann. N. Y. Acad. Sci., 121, 404 (1964).

9) L. Kolehmainen and J. Mikola, Arch. Biochem. Biophys., 145, 633 (1971).

10) P. C. Andrews, F. A. Schneider, D. Lebryk and L. G. Butler, Phytochemistry, 18, 1927 (1979).

11) A. Barth and G. Hermann, Biochem. Physiol.
Pflanzen, 166, 23 (1974).

12) L. A. Ott and J. G. Scandalios, Biochem. Genet., 14, 619 (1976).

13) T. C. Elleman, Biochem. J., 141, 113 (1974).

14) D. J. Toit and J. C. Schabort, Phytochemistry, 17, 371 (1978).

15) T. Sopanen and J. Mikola, Plant Physiol., 55, 809 (1975).

16) R. J. Delange and E. L. Smith, "The Enzymes (3rd ed.)," Vol. III, ed. by P. D. Boyer, Academic Press Inc., New York, N. Y., 1971, p. 81. 